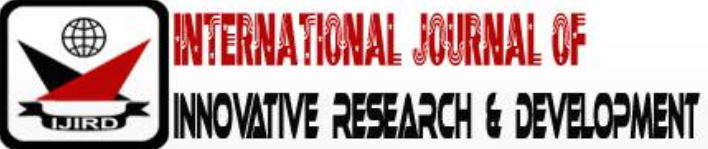

ISSN 2278-0211 (Online)

\section{Provisions Made for Curriculum Development in Ghana's 2007 Educational Policy: Any Lessons for Consideration by Stakeholders of Education in the Upper West Region}

\author{
Dr. Amina Jangu Alhassan \\ Senior Lecturer, Institute for Educational Planning and Administration (IEPA) \\ University of Cape Coast, Ghana
}

\begin{abstract}
:
The issue about curriculum development in the Ghana 2007 educational policy should be of concern to every stakeholder of education in the Wa Municipality. The level of excellence derived from any educational reform rests very much on how well the curriculum satisfies the needs of the pupils and society in general. An evaluation of the curriculum is one of the main approaches to determine whether a curriculum is implemented successfully and its benefits ripped by the pupils and other stakeholders of education whether in the Wa Municipality or the Ghana citizenry. The gap here is that the Wa Municipality has no empirical data to support the extent to which the provisions made for curriculum development has been implemented and achieved. The objective of the current study is to gather the views of stakeholders of education in the Wa Municipality on the subject matter. Analyze the views and arrive at conclusions that will evaluate the provisions listed under curriculum development. Three research questions were set to guide the study. A total sample size of 350 participants was contacted for the study. Purposive sampling strategy alongside the lottery method in simple random sampling and proportional allocation was used to select the sample from the accessible population. The data collection instruments were questionnaires and an interview guide and data were collected by a face-to-face meeting with participants and through correspondence over eight (8) weeks. Data analysis was qualitative with descriptive statistics to support the analysis of close-ended questions. The findings revealed that the provisions made for curriculum development to a large extent were implemented in the schools but, there are little benefits derived from the implementation process because pupils cannot fit into the job market or establish business venture after junior high school which is one of the main goals of the new curriculum under the Ghana 2007 educational policy. The current research has added to knowledge on the implementation of Ghana's 2007 educational policy reforms in the Wa Municipality. The research has revealed the level of success the policy has attained in the Wa Municipality with specific reference to the provisions made for curriculum development. Some members through the research instruments have come to know more about the policy and are ready to implement the provisions made for curriculum development than before.
\end{abstract}

Keywords: Curriculum, development, education, policy, implementation

\section{Introduction}

According to Braimah, Mbowura and Seidu (2014) after 57 years of independence Ghana's education sector have not established any roadmap for real development. All the policies are still under experimentation with no feasible solution to the many problems confronting the education sector (Braimah, Mbowura \& Seidu, 2014). Politicians see education as one of the tools, to propagate their core mandate and stay in power (Little, 2010). No matter how stagnant the development of the education sector may look like, there have been great strides in developing the school area regarding infrastructure, access, content and participation in recent years at all levels and in all the ten regions of Ghana (Ministry of Education, 2015). The progress, however, has not met the required standards needed for national development (UNICEF, 2012). We can measure this from the way scholarly output regarding skills and knowledge acquisition has reduced in recent years (Braimah et al., 2014). The recent development has created a lot of unemployment among school leavers raising concerns as to the relevance of our educational systems (Little, 2010). The rural poor, observe the challenges in the education sector and use that as a chance to revert to child labour as an opportunity cost, creating more challenges for the economy (Akyeampong, 2009).

The effects of leaving the education sector in the domain of politicians have affected educational outcomes negatively over centuries (Tyack \& Cuban, 1995). According to Tyack and Cuban (1995), the goals of education are long term whereas politicians have limited time to stay in office. Thus, the two scenarios do not allow for educational policies to be implemented fully. The question as to what should form the content of a school curriculum is a difficult one because it is hard to determine who is an educated person (Akpan \& Ogabo, 2014). Akpan and Ogabo (2014) raised concerns about what should be counted as education. Different communities have different perceptions of what constitutes success. Thus, 
how should a national policy on curriculum meet the diverse aspirations of the different values of the people is a critical issue that demands attention. It becomes more crucial when the comparison of what constitutes education is made between the Western and African perception of what should be considered as educational (Akpan \& Ogabo, 2014). On the local front, the situation is not different because the people of the northern hemisphere in Ghana have a different conception of what constitute good values as compared to the people of the middle belt and subsequently the southern zone. Determining a national curriculum that can satisfy the local needs of the people could be challenging but achievable. Ghana is not alone in this matter; India has a very sound national policy on education that was promulgated in 1968 by Prime Minister Indira Gandhi (Tilak, 2015). However, the Indian national policy on education also has challenges because there is a significant change in the landscape of all spheres of development, including the education sector (Tilak, 2015). For example, According to Tilak (2015), primary education is neglected, and areas that have been earmarked for reforms have not been fixed. Also, the various educational levels, mainly the primary, secondary, and higher education is not working in unison. Thus, they lack the cohesion and linkage required among them to function effectively for the Indian nation.

\subsection{Statement of the Problem}

Therefore, the researcher aims to publicize the views of stakeholders of education on how Ghana's 2007 educational policy has affected curriculum development in the Wa Municipality of the Upper West Region of Ghana. The purpose of this study is mainly to evaluate the extent to which the curriculum development provisions made in the Ghana 2007 education policy have implemented and benefited the pupils of Wa Municipality. It is also to make available information or feedback regarding how well the curriculum development provisions made in the Ghana 2007 educational policy have been implemented in the municipality.

\subsection{Research Questions}

The following three research questions were set to guide the study:

- How have pupils in the Wa Municipality benefited from the provisions made for curriculum development in Ghana's 2007 educational policy?

- What factors affect the implementation of the provisions made for curriculum development in Ghana's 2007 educational policy in the Wa Municipality?

- What strategies can enhance achievement from Ghana's 2007 educational policy concerning curriculum development in the Wa Municipality?

\subsection{Significance of the Study}

The study is significant because there is no much research on the progress of educational reforms in the Wa Municipality and for that matter the Ghana 2007 educational policy. This assessment gap is enough to call for empirical research in that area. Hence, the significance of the study lies in the fact that it will generate information on the strength, weaknesses, progress or regress of the policy in the Municipality.

\subsection{Delimitation and Limitations of the Study}

The current study is delimited to basic schools in the Wa Municipality. Again, the selection of Wa Municipality from among ten other districts is supported by Creswell (2013) who mentioned that selecting a single unit out of a lot for the study is supported by research principles. The only limitation for the current study is the fact that education is a continuous process and how well a curriculum would impact on the life of a pupil will require a long time beyond the basic level.

\section{Literature Review}

\subsection{Educational Reforms and Policies}

The 1992 Republican Constitution of Ghana indicated in unambiguous terms the right of every Ghanaian child to education. Thus, it is a fundamental human right for all Ghanaian children of school-going age to be in school. The right to education is guaranteed in the Ghanaian constitution to indicate the fact that every Ghanaian needs to develop their personality and potentials and that can be achieved through education (Ghana NGOs Coalition, 2014). To enforce the need for education, the right to education is enlisted in section 8 of the Children's Act. Other Acts that supports children rights including the right to education is the Universal Declaration of Human Rights. In 1995, Free and Compulsory Universal Basic Education (FCUBE) reform was a step in the right direction. Sackey (2008) reiterated the objectives of the FCUBE to include building human capacity to overcome the failure of the 1987 educational reforms. Reforms continue to flow in with little adjustments to physical inputs (Tagoe, 2011). Thus, the successful implementation of reforms continues to register failures Dewey, 1938; Little, 2010; Tagoe, 2011). In a study titled 'educational sector reforms in Ghana: a review' by Poku, Aawaar, and Worae (2013), they identify some phenomenon associated with educational reforms in Ghana that can be likened to the situation in the regions. According to the authors, Ghana's educational reforms have useful materials that can positively propel the nation's educational system. However, each of the reforms is saddled with the wrong approach to implementation leading to a situation that can be described as experimenting with Ghana's educational system. In a nutshell, the paper described Ghana's education system as a system without direction and focus (Poku, Aawaar \&Worae, 2013). 


\subsection{Curriculum Development and Implementation}

Nations have come to realize that issues concerning curriculum matter a lot to national development. Curriculum issues have direct relations to the quality of human resources a nation produces. The realization has brought a growing interest in matters that have to do with curriculum development (Brown, 2006). There are some issues regarding the national education curriculum in Ghana. Some of the provisions in the national curriculum are still modelled after the British school system some years ago. Even the British education system has moved away from these practices. Thus, some of the textbooks used in the Ghanaians school system needs to be reviewed. In some expert's view, the curriculum is limited and deficient of vital information that can propel the nation to achieve greater growth (Hilmer, 2001). The school curriculum focuses more on memorization and recalls to the detriment of practice and activities. In advanced countries, the focus is on individual problem solving, and that creates a critical thinking environment for students. We cannot build good human capital if the education system does not support that. The need for a quality human resource is more crucial in today's complex human societies than before (Hilmer, 2001). According to Hilmer (2001), the greatest challenge to educational development in Ghana has been the abandonment of initiatives and policies of past governments by present governments.

The sole purpose of educational reforms is to develop education to meet the needs of society (Dewey, 1938). Ghana is still battling with the educational system recording poor performance and massive unemployment over the years (Ghana News Agency, 2015). Scholars like Paul and Emmanuel (2014) reported a downward trend in pass rates among students who take part in the West Africa Secondary School Certificate Examination (WASSCE). The most affected students are from rural communities. According to the report, the West Africa Examination Council (WAEC) indicated that only $28 \%$ of pupils who took part in the 2014 WAEC examination qualified for tertiary education. The remaining $72 \%$ could not access higher education unless they sat for another examination. Meanwhile, the goal of the Ministry of Education is to ensure that the citizenry acquires skills that will make them functional in society (Ministry of Education, 2013). The goal could not be achieved if about $72 \%$ cannot access tertiary education unless they sat for another examination. In most cases, they sit for these examinations several times without success. Ghana is yet to fulfil this goal because students leave school ill-prepared to contribute anything meaningful to the development of the nation. It is widely known that companies re-train graduates to fit into their world of work. People blame the lapses in the education sector on inappropriate educational policies that lack a sense of direction because they are developed on inadequate information from the education sector. According to Dewey (1938), a teacher is at the grass root of the education sector and is confronted with the issues of the area directly, yet when it comes to generating policies for the education sector they are left out. It explains why most educational systems fail to achieve the desired goals (Dewey, 1938).

Report by Abdallah, Fuseini, Abudu and Nuhu (2014), stated that there has not been an improvement in pupils' performance before and after the Ghana 2007 education policy in the three northern regions. According to Abdallah et al. (2014), the poor academic performance among pupils is not just peculiar at the three northern regions but many other regions in the country. For these reasons, Ali (2006) thinks that a country like Ghana is paying lip service to the development of education (Ali, 2006). School children are studying under trees because they have no classrooms (Ali, 2006; Inkoom, 2012; Effah-Yeboah, 2012). Children from poor homes are left out because they cannot afford the cost of education. According to a report by Lucas (n.d.), it will cost US $\$ 200$ per year for a Ghanaian family to send a child to school. The figure is beyond the financial capability of many families in the municipality. It is against this background that some organizations come in to help needy families. One of such groups is the Women's Trust; an established to helped girls to stay in school in Ghana. In the event of this government of Ghana has launched an inclusive education policy to address the needs of children with special educational needs (Mwin, 2016). The policy is aimed at ensuring that children with special educational needs are catered for at the regular school environment without any form of discrimination. In other words, the policy recommended mainstreaming as the appropriate form of education for children with disabilities. Some scholars also blame the situation on the illiteracy of parents. The perception is supported by scholars like Ogbemudia and Aiasa (2013) and Yousefi (2010) who mentioned that parental level of education has an impact on a child's education. The study revealed that parents with less or no education have children who are poor performers in school whereas children with literate parents have demonstrated excellent academic performance in school (Ogbemudia and Aiasa, 2013). Some of the reasons for the phenomenon are the ability of parents to read pupils. Also, some scholars identified the lack of qualified teachers as the reason for the failure of educational policies.

\subsection{Quality Assurance Issues in Educational Policies}

Some factors determine the quality of an educational system and according to Mankoe (n.d.), the number of subjects' pupils learn at school is a factor. Mankoe (n.d.) noted that pupils are offering many subjects at the Junior High School level and that has negatively affected their performance. Meanwhile, it is commonly accepted that performance is one of the major indicators of assessing quality education. Mankoe (n.d.) argued that pupils are not always able to do a comprehensive study of each subject due to the limited time available for instruction. Thus, pupils complete the school term without any adequate preparation for their examination. It is not just pupils alone who suffer the setbacks (Mankoe, n.d.). According to Mankoe (n.d.) teachers are also negatively affected because they have volumes of preparations to do each day before they can instruct effectively. Mankoe (n.d.) report is supported by Adu-Agyem and Osei-Poku (2012) who indicated that it takes the performance of teachers to determine the quality of an educational system. The output of teachers goes a long way to impact on pupil's performance, and that is why Adu-Agyem and Osei-Poku (2012) believe that everything possible must be done to ensure that teachers are positively motivated. It is only when teachers are satisfied with the service conditions that they are prepared to work more (Adu-Agyem \& Osei-Poku, 2012). 
Additionally, Cassady (2011) indicated that the idea of teaching children with special needs in a general classroom had been a subject of discourse among stakeholders of education. While some people believe that it is better to separate children with special needs depending on the level of severity others, think inclusive education is the best strategy to develop the skills and talents of children with special needs (Cassady, 2011). Cassady (2011) conducted research to seek information on teachers' willingness to accept mainstreaming or inclusive education. The results suggest that the severity of the characteristics of the pupil informs the teacher's level of acceptance. For example, teachers were ready to accept children with autism in their class than allowing children with Emotion Behavior Disorder (Cassady, 2011). Tonhoma, Makombe and Ncube (2016) research support Cassady (2011) when they found out those teachers in mainstream primary school find it difficult to teach pupils with severe special learning needs. The teachers could not teach children with special needs because the schools lack the appropriate infrastructure that is user-friendly to support learners with disabilities. Tonhoma, et. al. (2016) recommended that schools must modify the existing infrastructure for the benefit of learners with disabilities. According to Ayanful (2016), even private schools are calling for support from government to enhanced quality in their schools. They have called on the government for assistance in the supply of teaching and learning materials including exercise books.

According to Asare and Nti (2014), the methods used in training student teachers do not promote the development of critical thinking skills. The process of teaching is both an art and science and without critical thinking, the art aspect is deficient in the teaching and learning process. Asare and Nti (2014) suggested that teacher education in Ghana requires new content. In a related study, Acharya and Joshi (2009) also mentioned that a teacher's drive or work attitude might also negatively influence the implementation of the school curriculum. There are, however, some researchers that disagree with the fact that learning materials can lead to poor academic performance. However, Asikhia (2010) discovered a contrary view to research reports that says that the lack of teaching and learning materials influence the academic performance of pupils negatively. Asikhia (2010) believes that the availability or no availability of teaching and learning resources did not impact on pupils' performance. The finding of Asikhia (2010) was a different one as many more types of research support the fact that lack of teaching and learning materials play a very crucial role in the academic performance of pupils. Contrary to the idea that only qualified teachers can perform better or implement educational policies better, recent investigations have proved that the effectiveness of teachers between trained and untrained teachers is relatively small. According to Charnor (2015) studies exploring teacher, effectiveness has found that teachers without certification or training may outperform those with certification or trained in Colleges of Education. Charnor (2015) stated that whatever system is used to employ teachers some will still not perform for undisclosed reasons.

\subsection{The Level of Politics and Stakeholders' Involvement in Educational Policy Formulation and Implementation}

In a statement by Villines (2014) everyone is invited to public policymaking; a process that makes it easy for the people to understand. Villines (2014) emphasized that decision making must involve all parties in a unit from bottom to top-level management. When this approach is adopted, it ensures that policies are implemented to the latter. As an individual, it may be difficult to influence the public policymaking process. However, with a group such as an organization, an association, or a community group it could be much easier. Other essentials are the need to identify government structures that handle public policymaking and work with them to represent your interests.

Education policy is not new in the field of education. They are systems very standard in the area of education centuries back in time. People's opinions about educational policies and politicking have not changed much. For example, Dewey's (1938) idea about the politicization of education is still relevant in contemporary times. Likewise, Tyack and Cuban (1995) perspectives on the assumptions and purposes of public education have not changed either. Education is so powerful that even within the same country over time the role of education changes. The latter view is supported by Senge (2012) when it was revealed that every new generation has debates on how their school system should function. The common perception is that schools have failed to meet societal expectations. Once society suffers it affects politicians directly, so they quickly find solutions to gain the confidence of the citizenry. In most cases, the solutions are not well implemented before they are sent out of office. The cycle continues with the new government, and more challenges are manifested due to the changing nature of society. In other words, before solutions are applied to continuing challenges new ones add up. That is how the complexity of balancing educational issues and implementation process has brought many educational systems in many nations on their knees Senge (2012).

It is not only in Ghana that politicians interfere with educational issues and policies. Education funding in Michigan and Pennsylvania faced similar controversial policies (Farley \& Everwine, 2014). The educational system of both states is funded by federal funds that easily dry up. Thus, putting schools under serious threat, and also making education funding a critical issue in political races in most states including Michigan and Pennsylvania (Farley \& Everwine, 2014). In a related study, Thomas (2012) reported that governors or presidents are not in a better position to run educational institutions because bureaucracy cripples public education. The education sector requires freedom of action by the teachers and heads of schools. Any laid down formula rather works against successful teaching and learning and schools. Thomas (2012) stated that bureaucracy fails to ensure successful implementation of educational policies because it honours leadership as against expertise that is a necessary ingredient for public education. Society has evolved into making public education an aspect of politics, to the extent that public education policies are used as tools for political campaigning.

Ghana should be able to identify the educational systems that work best for the country and improve upon them. Those that do not yield any benefits should be discarded. That is why a study of this nature is very crucial. We should stop recycling educational policies, and reforms that have not produced any better results, instead have jeopardized the educational system. For instance, we want to build more teacher training institutions when the current ones are 
underutilized, and we are supplying laptops to school children when there is no electricity to power them. We have only about $20 \%$ of students reaching the tertiary level due to poor performances (Bawa, 2012). Some of the poor performances are engineered by inexperienced teachers teaching pupils with little or no supervision. They are inexperienced because they have little or no training in the subjects they are teaching. Most teachers at rural schools are pupil teachers, the nickname for untrained teachers. Though some are good at work, a majority of them are underperformers. These and many more issues are enough reasons to consider our education sector a complete failure (Little, 2010; Bawa, 2012).

Ghana is not the only country asking questions about education and politics. Lamiell (2012), published a panel discussion from Press Room in Policy on the theme how should politics influence education policy? According to the panel discussions, local and state-level schools in America have been under the control of national politics. The group cited instances where governments in federal states have influenced educational policies. In the 2008 general elections, John McCain proposed a drastic budget cut that may have resulted in the loss of jobs by employees including teachers. Currently, if President Barrack Obama fails in the next elections, there is a high possibility that the Republicans may disregard the policies put in place by President Barrack Obama with the U.S. Department of Education. Ghana has already witnessed some of these issues. The National Democratic Congress (NDC) government revised the five-year Secondary education to three-year senior high school. On the assumption of office, the New Patriotic Party (NPP) administration reverted the three years to four years of Senior High School. The NDC is currently in office and has redirected the four years to three years of Senior High School (Eyiah, 2013). Dike (2005) recalls the need for politicians to stay out of educational policies because politicians are not stable in power. This is not limited to Nigeria but other African countries as well including Ghana. The panel made some strategies that can help to make national policy on education a reality. They include a national policy on education issues in political campaigns for voters to decide. Secondly, national media can open up a discussion forum on the issue to build a consensus. Lastly, countries can adopt already existing models in successful countries (Lamiell, 2012).

\subsection{Theoretical Framework}

Theories explain how nature works and by that theories may either be informative about what happens tomorrow and for that matter what ought to be done (Anfara \& Mertz, 2006). The theoretical framework guiding the study is grounded in the purpose of public education by Tyack and Cuban (1995) on why the Grammar of Schooling Persists (Tyack \& Cuban, 1995). The grammar of schooling they referred to as the basic standardized structures of schools which are long-rooted and difficult to change overnight. These basic standardized structures of schools are products of history and not by some reforms and as such, they become part of the school system. What Tyack and Cuban (1995) suggested that for successful implementation of reforms, reformers must engage the public and all stakeholders of education in a debate to ensure collective decision making before any attempt at changing the grammar of schooling (Tyack \& Cuban, 1995).

\section{Methodology}

The methodology section of empirical research gives the reader grounds to understand and appreciate the results or outcome of the study. Following what Creswell (2013) said, that the methodology section presents a clear outline of the methods used by the research, the research will present to the reader all the methods used to conduct the current research ranging from the site and population, the sample size and sample selection procedure and the data analysis plan. Others include the test for validity and reliability and the pilot study.

A case study design is used for the current research. It is used because it allows the researcher to comprehensively collect and analyze data for the topic under investigation (Creswell, 2013). The site of the study is the Wa Municipal in the Upper West Region of Ghana. The population of the Wa Municipality from the last census stood at 107,214 consisting of 52,996 males and 54,218 females (Ghana Statistical Service, 2012). The population of the study includes; all head teachers and teachers in the municipality, parents, the Regional Minister, the Municipal Chief Executive, the staff of the Regional and Municipal Offices including the Directors. The researcher believes that the identified target population will provide information for the successful completion of the study. The population of the target group in the Municipality stood at 2,164 members (Upper West Regional Education Office EMIS, 2015). The breakdown is as follows: Head teachers 205; teachers 1,774; Wa Municipal Education Office staff 70; Wa Regional Education Office 63(Source: Upper West Regional Education Office EMIS, 2015). Also, we have the Regional Minister of Upper West Region and The Municipal Chief Executive and50parents purposively selected.

\subsection{Sample Size and Sampling}

According to Kothari (2004) and Creswell (2009), it is permissible to draw a sample from the target population for various reasons. To determine the operational sample size for the study, the Tables provided by Sarantakos (1998, $p$. 163) were utilized. However, the proposed sample size from the Tables was large and the researcher decided to engage a lesser sample size to avoid history affecting the results. From the Tables, a population size of 2,164 attracted a sample size of 564 but the researcher used a sample size of 356 which is acceptable in qualitative studies (Creswell, 2009). In operationalizing the sample selection simple random sampling and purposive sampling strategies were used. The Regional Minister, Municipal Chief Executive, Municipal Director of Education and the Regional Director of Education were all purposively sampled including the fifty (50) parents. The staff of the Regional Education Office and Staff of Municipal Education Office were simple randomly sampled using the lottery method. Purposive sampling was also used to select teachers and head teachers from the accessible population (Patton, 1990; Kothari, 2004; Creswell, 2013; Patton, 2002; Frankfort \& Nachmias, 2008). The analysis of the selection of the sample is presented in Table 1. 


\begin{tabular}{|c|c|c|c|}
\hline Members & $\begin{array}{c}\text { Number of } \\
\text { Members }\end{array}$ & $\begin{array}{c}\text { Number of Members } \\
\text { Suggested by the Tables }\end{array}$ & $\begin{array}{c}\text { Number of Members } \\
\text { Finally Selected }\end{array}$ \\
\hline Regional Minister & 1 & - & 1 \\
\hline Municipal Chief Executive & 1 & - & 31 \\
\hline $\begin{array}{c}\text { Staff of Regional Education } \\
\text { Office }\end{array}$ & 63 & 52 & 33 \\
\hline $\begin{array}{c}\text { Staff of Municipal } \\
\text { Education Office }\end{array}$ & 70 & 132 & 80 \\
\hline Head teachers & 205 & 317 & 160 \\
\hline Teachers & 1774 & - & 50 \\
\hline Parents & - & 564 & 356 \\
\hline Total & 2,164 & & \\
\hline
\end{tabular}

Table 1: The Sample Size

Source of Number of Members: Upper West Regional Education Office,

Education Management Information System (EMIS) (2015)

\subsection{Data Collection Instruments/Collection Procedure}

Two data collection instruments were used to collect data for the study. They are a questionnaire and an interview guide. Creswell (2013) made an indication that the use of two or more tools to collect information for a study is very credible since the multi-tools overcome their weaknesses whiles strengthening their benefits (Creswell, 2013). The item raised on both the interview guide and the questionnaire were validated using content-related validity (Patton, 2002). Twelve (12) questions were set for both the questionnaire and interview guide. The questions were made up of both close and opened-ended questions. The Twelve (12) questions were spread over Four (4) sections. The statements or questions are provisions made in the Ghana 2007 policy on education concerning curriculum development.The categorization of the items into sections is to facilitate the thematic data analysis process (Creswell, 2013). The questionnaires had a $98 \%$ return rate and all the members selected for the interview participated. Data was collected over eight weeks. Both correspondence and a face-to-face meeting with members were adopted. A Pre-Test was conducted to ensure that corrections were made before the instruments were administered to the larger population sample (Patton, 2002; Creswell, 2013). Out of the Three hundred and fifty (356) participants, 98\% consisting of Three hundred and fifty (350) members completed the task of answering questions to support the study. Six questionnaires consisting of $2 \%$ were not retrieved.

\subsection{Data Analysis Plan}

Mainly, qualitative analysis of data was used to analyze the data with the support of descriptive statistics to analyze close-ended questions for easy interpretation (Creswell, 2009). Thus, the SPSS software was used to compute data on close-ended questions into frequencies and percentages while thematic analysis of data was used to describe the opened-ended questions. Using a thematic analysis of data involved summarizing data from opened-ended questions into themes for analysis (Patton, 2002). Themes were identified from the research questions and used as such. The biggest challenge of repeatability was overcome by using the thematic analysis of data strategy (Gibbs, 2002).

\section{Results and Discussion}

According to Creswell (2013) and Frankfort-Nachmias \& Nachmias (2008) data can be merged for presentation and analysis. It is against this background that data from the questionnaires and interviews concerning Gender and Occupation of Members were merged for ease of analysis. The results for gender are presented in Table 2.

\begin{tabular}{|c|c|c|c|c|c|}
\hline \multicolumn{2}{|c|}{ Variables } & Frequency & Percent & Valid & Cumulative \\
\hline Valid & Male & 215 & 61.4 & 61.4 & 61.4 \\
\hline & Female & 135 & 38.6 & 38.6 & 100.0 \\
\hline & Total & 350 & 100.0 & 100.0 & \\
\hline
\end{tabular}

Table 2: Gender of Members

There were more males than females participating in the study. From the 350 participants, 215 consisting of $61.4 \%$ were males whereas 135 consisting of $38.6 \%$ were females. The results for Category of Members are presented in Table 3. 


\begin{tabular}{|c|c|c|c|c|c|}
\hline \multicolumn{2}{|c|}{ Variables } & Frequency & Percent & $\begin{array}{c}\text { Valid } \\
\text { Porcont }\end{array}$ & $\begin{array}{c}\text { Cumulative } \\
\text { Parcant }\end{array}$ \\
\hline Valid & Regional Minister & 1 & 0.3 & 0.3 & 0.3 \\
\hline & Municipal Chief Executive & 1 & 0.3 & 0.3 & 0.6 \\
\hline & Regional Director of Education & 1 & 0.3 & 0.3 & 0.9 \\
\hline & $\begin{array}{c}\text { Municipal Director of } \\
\text { Education }\end{array}$ & 1 & 0.3 & 0.3 & 1.2 \\
\hline & $\begin{array}{c}\text { Staff of Regional Directorate of } \\
\text { Education }\end{array}$ & 30 & 8.6 & 8.6 & 9.8 \\
\hline & $\begin{array}{c}\text { Staff of Municipal Directorate } \\
\text { of Education }\end{array}$ & 32 & 9.1 & 9.1 & 18.9 \\
\hline & Head teachers & 80 & 22.8 & 22.8 & 41.7 \\
\hline & Teachers & 154 & 44.0 & 44.0 & 85.7 \\
\hline & Parents & 50 & 14.3 & 14.3 & 100.0 \\
\hline
\end{tabular}

Table 3: Category of Members

The head teachers represent $80(22.8 \%)$, teachers $154(44.0 \%)$ while parents represent $50(14.3 \%)$. The staff of Regional Directorate represented 30(8.6\%) while the Municipal Directorate of Education represented 32(9.1\%). The rest is the Regional Minister, Municipal Chief Executive, Regional Director of Education, and Municipal Director of Education represented $1(0.3 \%)$ for each member.

4.1. How Have Pupils in the Wa Municipality Benefited from the Provisions Made for Curriculum Development in Ghana's 2007 Policy on Education?

Items under Section B were designed to find answers to research question 1. Members were to select from a scale of five options ranging from strongly agree to undecided on the questionnaire (Creswell, 2013; Frankfort-Nachmias \& Nachmias, 2008). The results are shown in Table 4.

\begin{tabular}{|c|c|c|c|c|c|}
\hline Ratings & $\begin{array}{c}\text { Strongly } \\
\text { Agree }\end{array}$ & Agree & Disagree & $\begin{array}{l}\text { Strongly } \\
\text { Disagree }\end{array}$ & Undecided \\
\hline Items & $f(\%)$ & $f(\%)$ & $f(\%)$ & $f(\%)$ & $f(\%)$ \\
\hline $\begin{array}{l}\text { Q3. At the lower primary level } \\
\text { English, Natural Science, Basic } \\
\text { Mathematical Skills, and the } \\
\text { dominant Ghanaian language of } \\
\text { the area are taught in the schools }\end{array}$ & $140(50 \%)$ & $126(45 \%)$ & $10(3.6 \%)$ & $04(1.4 \%)$ & $00(00 \%)$ \\
\hline $\begin{array}{l}\text { Q4. At the upper primary level } \\
\text { subjects include the dominant } \\
\text { Ghanaian language of the area, } \\
\text { English, Basic Mathematical Skills, } \\
\text { Integrated Science, and citizenship } \\
\text { Education. }\end{array}$ & $155(55.4 \%)$ & $114(40.7 \%)$ & $08(2.9 \%)$ & $02(.7 \%)$ & $01(.4 \%)$ \\
\hline $\begin{array}{l}\text { Q5. At the primary level, Physical } \\
\text { Education, Music and Dance, and } \\
\text { other Creative Arts are taught in } \\
\text { the schools as practical subjects }\end{array}$ & $54(19.3 \%)$ & $156(55.7 \%)$ & $54(19.3 \%)$ & $05(1.8 \%)$ & $11(3.9 \%)$ \\
\hline $\begin{array}{l}\text { Q6. At the Junior High School level, } \\
\text { English, Mathematics, Social } \\
\text { Studies, Integrated Science, a } \\
\text { Ghanaian language, Technical, } \\
\text { Vocational, Technical, and } \\
\text { Agricultural Education, and } \\
\text { French are taught in the schools }\end{array}$ & $102(36.4 \%)$ & $155(55.4 \%)$ & $20(7.1 \%)$ & $3(1.1 \%)$ & $0(00 \%)$ \\
\hline $\begin{array}{l}\text { Q7. Guidance and Counseling are } \\
\text { offered to pupils to enable them to } \\
\text { choose the right programs and } \\
\text { schools. }\end{array}$ & $66(23.6 \%)$ & $127(45.4 \%)$ & $61(21.8 \%)$ & $20(7.1 \%)$ & $06(2.1 \%)$ \\
\hline $\begin{array}{l}\text { Q8. There is a curriculum } \\
\text { planned to meet the needs of } \\
\text { children and youth with } \\
\text { special educational needs in } \\
\text { the Municipality }\end{array}$ & $42(15 \%)$ & $108(38.6 \%)$ & $86(30.7 \%)$ & $28(10 \%)$ & $16(5.7 \%)$ \\
\hline $\begin{array}{l}\text { Q9. Pupils' can set up their } \\
\text { trade after Junior High School } \\
\text { based on the training they } \\
\text { received }\end{array}$ & $19(6.8 \%)$ & $36(12.9 \%)$ & $129(46.1 \%)$ & $90(32.1 \%)$ & $06(2.1 \%)$ \\
\hline
\end{tabular}

Table 4: Results on the Benefits Gained from the 2007 Educational Policy Provisions Made for the School Curriculum 
To have a three-way perception of members views for purposes of convenience of analysis, strongly agree and agree are merged and interpreted as agreeing whereas strongly disagree and disagree are merge and described as disagree (Creswell, 2009; Patton, 2002; Creswell, 2013; Frankfort-Nachmias \& Nachmias, 2008).From the presentations on Table 4, out of the 280 members who participated in answering the questionnaire, a larger majority of members representing 266 (95\%) said they agree with the statement made under item 3. While a little minority of members representing $14(5.0 \%)$ disagree with the statement. No member indicated that they were undecided on the statement. During the interview session, the following results were gathered for the same statement. Out of the 70 members interviewed $45(64.3 \%)$ agree with the statement whereas $25(35.7 \%)$ disagree with the statement.

The next item 4 on Table 4 has a vast majority of members representing $269(96 \%)$ saying they agree with the statement. While a little minority of members representing 10 (3.6\%) disagree with the statement. One member representing $0.4 \%$ was undecided about the statement. Again, out of the 70 members interviewed a vast majority of members 48(68.6\%) agree with the statement whereas a small minority of members $22(31.4 \%)$ registered their disagreement with the statement. The next item 5 also recorded a vast majority of members 210(75\%) agree to the statement. Whereas a little minority of 59(21.1\%) disagree to teach statement. $11(3.9 \%)$ of members were undecided on the issue. The interview results were as follows; $32(45.7 \%)$ agree to the statement whereas the majority of members $38(54.3 \%)$ disagree with the statement.

Data gathered on the next item 6 presented a vast majority of members $257(91.8 \%)$ agreeing to the statement. A small number of $23(8.2 \%)$ members disagree with the statement. The information gathered from members interviewed on the same subject matter had a majority of $42(60 \%)$ members agree to the statement, whereas $28(40 \%)$ of members disagree with the statement. The next item 7 recorded a vast majority of members representing 193(69\%) agree to the statement. The minority of members $81(28.9 \%)$ disagree with the statement. Whereas $6(2.1 \%)$ were undecided on the issue. The results from the interview session were not different from that of the questionnaire. The majority of $48(69 \%)$ members agree to the statement with only $22(31 \%)$ of members did not agree with this statement. The Ghana 2007 educational policy also made provisions for children with special needs. Thus, the next item 8 in Table 4, unlike the previous items where there is a wider gap between majorities of members that supported the statements, the results for this item showed a smaller difference between the majority and minority views. Out of the 280 members, $150(53.6 \%)$ agree to the statement. While $114(40.7 \%)$ of the members disagree with the statement. As many as $16(5.7 \%)$ were undecided on the statement. Members interviewed out of the 70 has less than average 33(47\%) agree to the statement while a little above average 37(53\%) disagree with the statement. The last item 9 on the list recorded a small minority of members 55(19.7\%) agree to the statement whereas alarge majority of members representing 219(78.2\%) disagree with the statement. Only $6(2.1 \%)$ members were undecided on the statement. Out of the total number of members interviewed $9(13 \%)$ agree to the statement whereas a large majority of members representing 61(87\%) disagree with the statement.

By way of discussion, the analysis presented on Table 4 and from the interview shows that a large majority of members support the fact that the curriculum is being implemented but together with the minority of members think that there are numerous challenges facing the implementation process. Members are saying that pupils cannot be self-employed upon completion of Junior High School because they did not receive enough practical training and lack employable skills. In order to earn a living, they need to undergo an apprenticeship with their private masters for several years. This is supported by Abdallah et al. (2014) when they stated that there has not been an improvement in pupils' performance before and after the Ghana 2007 education policy in the three Northern Regions. According to the report before Ghana 2007 educational policy, the pass rate for both Mathematics and English has not gone beyond 47\% in the three Northern regions (Abdallah et al., 2014). The situation was still the same after the introduction of the Ghana 2007 educational policy because by the year 2010 and 2012 the pass rate was at 46.4\% and 41.1\% respectively for Mathematics and English (Abdallah et al., 2014).The figures are rather showing a decline in the standard of education, especially in Mathematics and English. Members attributed the failure of the school to implement the curriculum to lack of qualified teachers, lack of the appropriate resources for effective teaching and learning, and lack of teacher motivation, and the absence of parent's involvements in pupil'seducation. Charnor (2015) suggested that high-stakes decisions about teachers in the service must be based on some teacher performance measures such as placing newly recruited teachers on probation during which period their performance is evaluated, and decisions are taken as to whether they can teach.

4.2. What Factors affect the Implementation of Ghana's 2007 Policy on Education under Curriculum Development in the Wa Municipality?

The results for research question 2 are presented in Table 5, Figure 1 and 2.

\begin{tabular}{|c|c|c|c|c|c|}
\hline \multicolumn{2}{|c|}{ Variables } & Frequency & Percent & $\begin{array}{c}\text { Valid } \\
\text { Percent }\end{array}$ & $\begin{array}{c}\text { Cumulative } \\
\text { Percent }\end{array}$ \\
\hline Valid & Yes & 301 & 86.0 & 86.0 & 86.0 \\
\hline & No & 49 & 14.0 & 14.0 & 100.0 \\
\hline & Total & 350 & 100.0 & 100.0 & \\
\hline
\end{tabular}

Table 5: Data on whether there are Factors Affecting the Implementation of the Curriculum Provisions

Out of the 350 members, a larger majority of members representing 301(86\%) said factors are affecting the implementation of the curriculum provisions. A little minority of members representing $49(14 \%)$ stated that no factors are affecting the implementation of the curriculum provisions. The reasons members advanced for their choice of yes 
response for the statement were grouped under seven common themes and presented in Figure 1. Data represents both the questionnaire and the interview results.

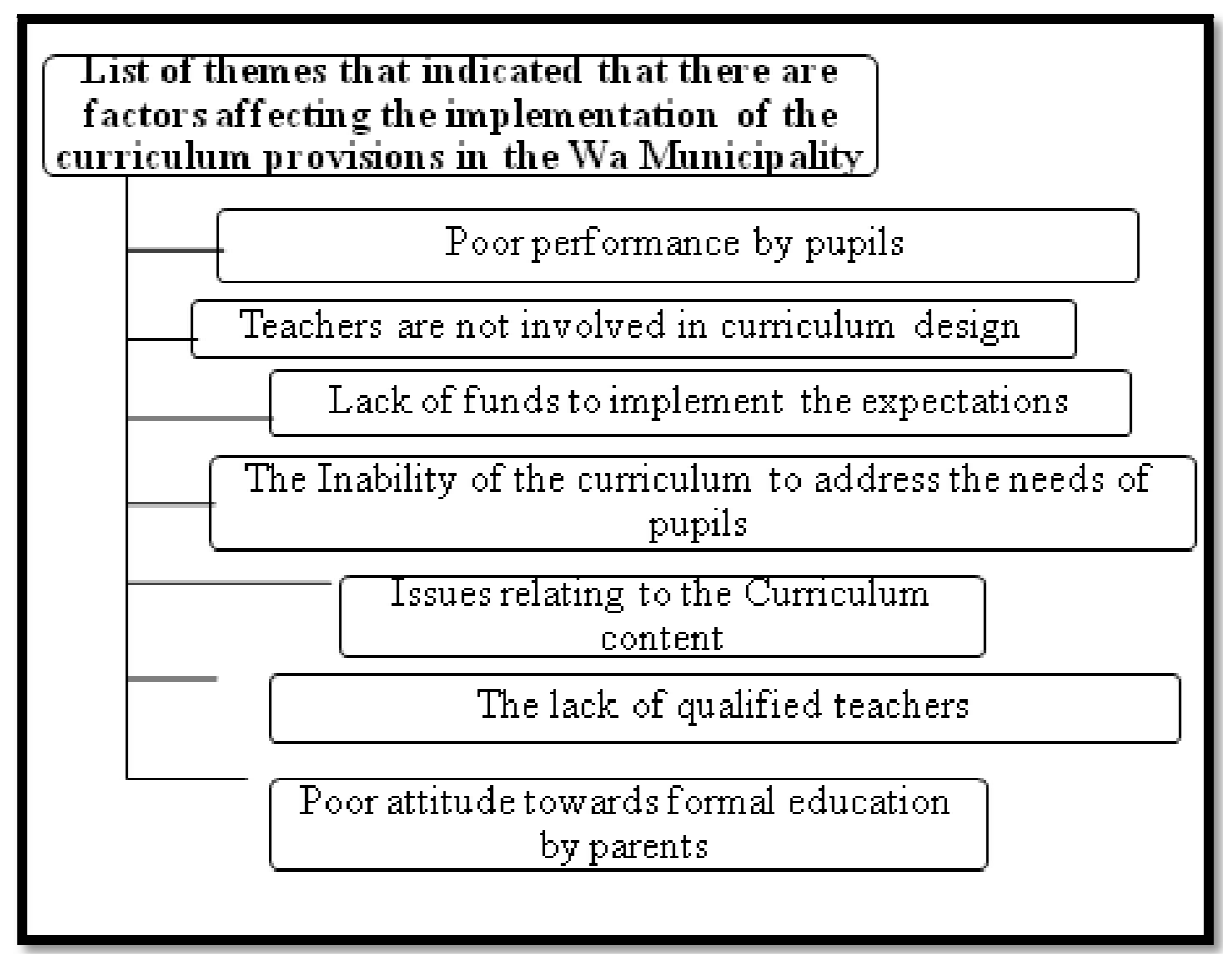

Figure 1: List of Themes Identified from the Questionnaire and the Interview That Indicated That Factors Are Affecting the Implementation of the Curriculum Provisions in the Ghana 2007 Educational Policy in the Wa Municipality

Source: Author

There is some literature to support the views of members on the issue of unsuccessful implementation of the school curriculum and its effects on pupils' development. For example, the effect on poor performance is supported by Abdallah et al. (2014) when they stated that performance has not improved after the introduction of the Ghana 2007 educational policy. Etsey (2005) also noted that teaching and learning materials play a crucial role in effective teaching and learning. Where teaching and learning materials are available, it is easier for teachers to work successfully to accomplish the task of teaching their lessons and completing the syllabus. In a related study, Acharya and Joshi (2009) also mentioned that a teacher's drive or work attitude might also negatively influence the implementation of the school curriculum. There are, however, some researchers that disagree with the fact that learning materials can lead to poor academic performance. Asikhia (2010) discovered a contrary view to research reports that says that the lack of teaching and learning materials influence the academic performance of pupils negatively. In Asikhia (2010) case the availability or no availability of teaching and learning resources did not impact on pupils' performance.

Again, members noted that due to lack of supervision teachers are concentrating on their studies than teaching in the classroom and that is affecting the implementation of the curriculum. It is common to hear teachers say they have not completed their syllabus at the end of every school term. The large class sizes are also affecting teacher performance, and according to members most classes in the Municipality are overcrowded with some classes having as many as 70 to 80 pupils. Teachers spend a lot of time to get every child to benefit from the lessons of the day, and that is a contributory factor to the delay in completing the syllabus for a school term. Thesituation is worsening by the phenomenon of teacher absenteeism. The observation of members is supported by a report that featured on Ghana News Agency (2013). According to the report, the Ghana National Association of Teachers (GNAT) has complained of high teacher absenteeism in schools and the Wa Municipality is no exception. The situation is worst in rural communities in the Wa Municipality where the school environment is weak and teacher morale very low. Another issue that members mentioned was the absence of teachers' involvement in formulating decisions concerning the education sector. It is a phenomenon that is supported by what Ali (2006) noted that education policies fail because of the over-centralization of decision-making and or policy formulation. The same phenomenon was discussed centuries ago by Dewey (1938) and Tyack and Cuban (1995) and is persisting to date. Teachers need to be involved in the educational policy decision-making process to increase their commitment to the implementation process.

The lack of funds was also identified as a critical issue that impedes the practicality of the curriculum provisions. According to a report by Lucas (n.d.), it will cost US\$200 per year for a Ghanaian family to send a child to school. The figure is beyond the financial capability of many families in the municipality. Members were also quick to mention that curriculum developers do not consider the needs of children with particular disabilities. Children with disabilities often find themselves dropping out of school because they cannot cope with normal class settings. According to Cassady (2011), the idea of teaching children with special needs in a general classroom environment has been a subject of discourse. While some people believe that it is better to separate children with special needs depending on the level of severity others, 
think inclusive education is the best strategy to develop the skills and talents of children with special needs (Cassady, 2011). Cassady (2011) conducted research to seek information on teachers' willingness to accept mainstreaming or inclusive education. The results suggest that the severity of the characteristics of the pupil informs the teacher's level of acceptance. For example, it was discovered that teachers were ready to accept children with autism in their class than allowing children with Emotion Behavior Disorder (Cassady, 2011). Another research that supports member's observation is a report by Tonhoma et al. (2016) who stated that teachers in the mainstream at the basic level find it a challenging task to teach pupils with special learning needs. In most cases, it is not the lack of skills but the lack of appropriate teaching and learning resources that prevent teachers from helping pupils with special learning needs in the classroom (Tonhoma et al., 2016). Tonhoma et al. (2016) recommended the establishment of a learner-friendly environment for learners with disabilities. In the event of this government of Ghana has launched an inclusive education policy to address the needs of children with special educational needs (Mwin, 2016).

The policy is aimed at ensuring that children with special educational needs are catered for at the regular school environment without any form of discrimination (Mwin, 2016). There were also issues like the lack of qualified teachers in the Municipality as a hindrance to achieving the provisions made not just for the school curriculum and the lack of funds to finance the programmes. It is against this background that Asare and Nti (2014) noted that the government must focus on giving quality training to teachers by adding new content and introducing new strategies. The move will ensure quality training that will enable teachers to develop critical thinking skills to enhance their performance (Asare \& Nti, 2014). Members have also identified high illiteracy rate on the part of parents as another factor negatively affecting the achievement of goals laid down in the policy for curriculum development. The perception is supported by scholars like Ogbemudia and Aiasa (2013) and Yousefi (2010) who mentioned that parental level of education has an impact on a child's education. The study revealed that parents with less or no education have children who are poor performers in school whereas children with literate parents have demonstrated excellent academic performance in school (Ogbemudia and Aiasa, 2013).

Some members were of the view that no factors are affecting the implementation of the provisions made for curriculum development. Four common themes were identified and presented in Figure 2.

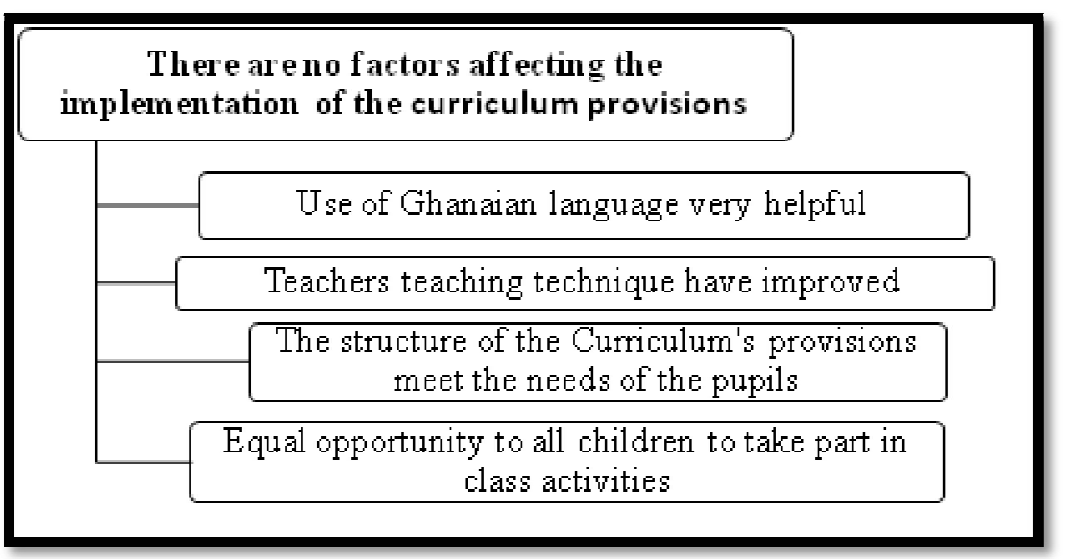

Figure 2: List of Themes Identified from the Questionnaire and Interview Session That State That No Factors Are Affecting the Implementation of the Provisions Made for Curriculum Development Source: Author

Determining what should form part of the school curriculum and at the same time meets the needs of individual pupils could bea big dilemma. It is against this background that Akpan and Ogabo (2014) observed that it's difficult to determine who an educated person is because different communities have a different perception of what can be counted as education. However, as a nation, there are some considerations on national aspiration and that informs what goes into the national curriculum for education. In that case, the assertion of Akpan and Ogabo (2014) about what to include on national curriculum is solved when countries consider national aspiration than selfish individual needs. Members think that after careful considerations the policy planners presented appropriate provisions for inclusion in the curricula.

Again, members claimed that assigning any failure to the curricula may be misleading because it could be factors related to the implementation process and not necessarily the curriculum provisions outlined in the Ghana 2007 educational policy. The observation is supported by a submission made by Paul and Emmanuel (2014) when they stated that, it is not right to always blame students for not preparing well for their examinations. Their failures could be more of a lack of supervision from school authorities or the much political interference in education the country continues to experience. The reasons for students' failure in an examination are as complex as the subject of individual difference. A variety of circumstances plays different roles in determining how successful a student can be when it comes to academic performance (Paul \& Emmanuel, 2014). The same applies to the implementation and success of any educational policy.

\subsection{What Strategies Can Enhance Achievement from the Provisions Made for Curriculum Development in Ghana's 2007 Educational Policy in the Wa Municipality?}

Item under Section $\mathrm{D}$ for both the questionnaire and interview guide seek to find out what strategies can improve benefits from the Ghana 2007 educational policy in the Wa Municipality with specific reference to the provisions made for 
curriculum development. Eight broad common themes were identified from the questionnaire data and interview. The results are presented below in Figure 3.

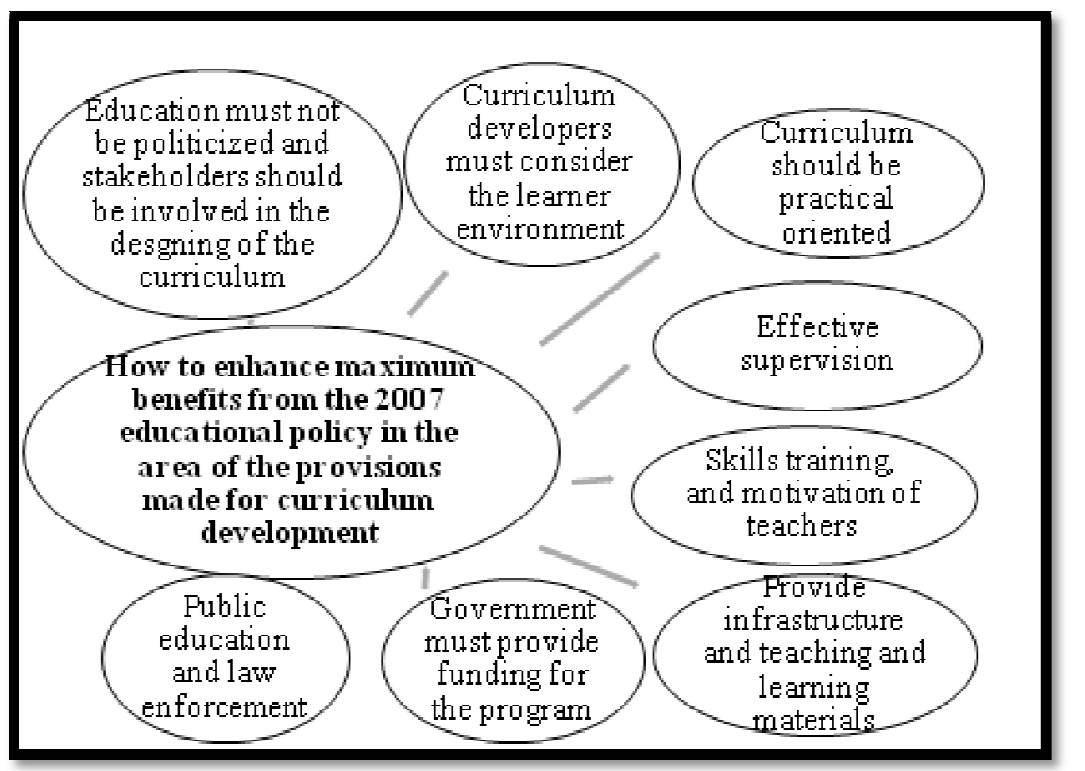

Figure 3: List of Themes Identified from Data Gathered for Both the Questionnaire and from the Interview Session That Will Enhance Maximum Benefits from the Ghana 2007 Educational Policy in the Areas of Curriculum Development Source: Author

Members indicated that politicizing education policy by politicians must stop and that all stakeholders of education in the Wa Municipality must be involved in decision-making concerning the school curriculum. Again, members suggested a broader consultation with other social organizations as a step towards identifying sustainable programs that will be included in the curriculum. This suggestion about politicizing education policy goes to support what Poku et al. (2013) said about politicians and educational policies. According to Poku et al. (2013), it is very common to see politicians who form the government of the day reversing policies of their opponents just to score political points (Poku et al., 2013). The next theme identified for consideration is that of the learner environment. Members believed that curriculum developers must always consider the learner environment when developing the curriculum. That can be achieved through consultation with teachers, parents, and the pupil themselves. Akpan and Ogabo (2014) submission agree with the current suggestion that what constitutes the learner environment and education can be varying between and among people of different origin and according to their needs. For example, Western perception about education may be different from Africans perception about what constitutes education. Akpan and Ogabo (2014) believe that on the local front the situation is not different because the people of Ghana belong to different clans and different families that share different values. Even considering the Municipality, some many ethnic groups and families are difficult to ignore. Thus, the northern hemisphere, the middle belt, and subsequently the southern zone have a different conception of what constitute good values. Therefore, to determine a curriculum that can satisfy the local needs of the people according to Akpan and Ogabo (2014) could be challenging but achievable.

Members also stated that the school curricula are bookish and lacks the practical aspect that characterized its provisions. This observation is supported by what Inkoom (2012) stated that some Ghanaian children are attending schools that cannot prepare them for the job market because schools lack infrastructure, resources and teachers to prepare them for the job market (Inkoom, 2012).Thus, the equipment required for technical, vocational, and Information and Communication Technology teaching are not available and should be provided for schools. Again, members observed there is a direct link between achieving the provisions made in the curriculum and the quality of teachers in the classroom. Members suggested that all untrained teachers must be trained as a matter of urgency, while plans are put in place for the consistent upgrading of teacher's skills to reflect current trends in the fields and societal needs in particular. The current suggestion is supported by what Asare and Nti (2014) stated that the quality of the teacher is very crucial to the successful implementation of any educational policy. According to Asare and Nti (2014), the current methods used by Colleges of Education in training student teachers do not promote critical thinking skills. Therefore, teacher training and development in Ghana and for that matter the Wa Municipality require new content and modern techniques of teaching student teachers. Supervision of teachers on the job as well as the monitoring of schools, teachers, and management must be consistent and frequent to achieve results. Members also observed that when teachers are well motivated, it will boost their morale and increase performance and that will ensure maximum delivery in the classroom.

The provision of infrastructure, teaching and learning resources were also identified as one of the crucial elements in achieving the objectives of the curriculum and also public education. They noted that public education on the policy has not received much attention leading to misunderstandings between school authorities and parents, especially when it comes to financing education. This is supported by what Adu-Agyem and Osei-Poku (2012) said that state institutions must supply educational materials to schools. Eyiah (2013) also noted that the government needs to focus on 
how to build infrastructure as much as supplying teaching and learning materials to schools to ensure the successful implementation of educational policies including the one under investigation.

\section{Summary/Conclusion}

A greater majority of members observed that the curriculum is relevant per its content and once implemented it will benefit the pupils. There were also submissions to the effect that all the subjects listed in the curriculum were taught in the schools and are of benefit to the pupils. However, there were objections to the relevance of the curriculum by minority members. They think that once the curriculum is facing serious challenges in its implementation, it suggests that it is not relevant to the pupils in its current state. Several reasons were given by members to support their views. For instance, members cited the Junior High School curriculum as one that requires practical training of pupils in some technical subjects. However, the lack of resources to achieve this objective has negatively affected the relevance of the policy. Therefore, the objective that pupils will complete Junior High School with employable skills for the job market is defeated. Again, members reiterated the policy emphasized on training the youth in Information and Communication Technology (ICT). A necessary skill required in the current modern socio-economic environment, where cyber literacy is a crucial commodity for the job market. Meanwhile, with all the emphasis schools continue to lack the necessary inputs such acquisition of hard and software products of ICT to train the pupils, as well as teachers in the field of ICT. Members acknowledge that the government have identified and put in place some cross-cutting measures that could speed up the achievement of the policy goals. Unfortunately, few of the cross-cutting measures are functional in the Wa Municipality. They include Library and Information Services, the establishment of science laboratories, technical skills workshops. Most of the school libraries have outmoded books and materials that do not comply with the demands of the current curriculum.

By way of suggestions, members noted that linking the local industry to the school curriculum will create harmony between the two. Members believe this is necessary because there is no linkage between the local industry and some of the provisions made in the curriculum. For example, the local industries in the Wa Municipality are cloth weaving, shea-butter making, guinea fowl farming, soap making, and leather shoe and bag making. If some of these trades were included in the school curriculum, pupils would graduate from school with employable skills. Thus, because they are not taught, there is a disconnection between local industry and what practical skills are taught in the classroom. It is only when the practicalities are taught in the classroom that the curriculum can be more relevant to the needs of the pupils.

It is very clear from the analysis of the results that changes may be relevant or useful, but until they are implemented successfully, they remain irrelevant. Thus, lack of funds from the government to finance the provisions made in the 2007 education policy, teachers' lack of commitment to the job due to poor recognition and service conditions, parents' lack of knowledge about education policy which has prevented them from exercising maximum support for educational policies and reforms, and the lack of monitoring and supervision of education policy to determine their level of operationalization have all contributed to hindering the successful implementation of education policy in the Wa Municipality. Achieving educational goals is like a football game where putting the ball in the back of the net is a victory crowning the efforts of the team. Therefore, achieving educational goals must be a collective effort of all stakeholders of education in the Wa Municipality.

\section{Recommendations}

- The Municipality must embark on sourcing funds to support educational programmes, especially in securing educational materials and structures for teaching and learning.

- There must be a public forum to educate all stakeholders of education on educational policies and this can be done during seminars, festivals and durbars in the Municipality.

\section{References}

i. Abdallah, H., Fuseini, M. N., Abudu, A. M., \& Nuhu, Y. (2014, September 1). Dilemma of basic school pupils in northern Ghana with respect to their learning context. Education Research International. Retrieved 27th July, 2016 from http://www.hindawi.com/journals/edri/2014/140737/

ii. Acharya, N., \& Joshi, S. (2009). Influence of parents' education on achievement motivation of adolescents. Indian Journal Social Science Researches, 6(1), 72-79.

iii. Adu-Agyem, J., \& Osei-Poku, P. (2012). Quality education in Ghana: The way forward. International Journal of Innovative Research \& Development, 1(9), 164-177.

iv. Akpan, C. 0., \& Ogabo, G. A. (2014, September). Who is the educated man? A comparative inquiry on the African and Western conceptions. American Journal of Social Issues and Humanities, 4(5), 335. Retrieved 18th February, 2016, from http://www.ajsih.org/index.php/ajsih/article/view/169/160

v. Akyeampong, K. (2009). Revisiting free compulsory universal basic education (FCUBE) in Ghana. Comparative Education, 45(2), 175-195.

vi. Ali, S. (2006). Why does policy fail? Understanding the problems of policy implementation in Pakistan - a neuro-cognitive perspective. International Studies in Educational Administration, 34(1). Retrieved 27th July, 2016 from http://ecommons.aku.edu/pakistan_ied_pdck/10/

vii. Anfara, V., \& Mertz, N. T. (2006). Theoretical frameworks in qualitative research. Thousand Oaks: Sage Publications Inc.

viii. Asare, K. B. and Nti, S. K. (2014). Teacher Education in Ghana: A Contemporary Synopsis and Matters Arising. SAGE. Doi: 10.1177/2158244014529781 
ix. Asikhia, O. A. (2010). Students and teachers' perception of the causes of poor academic performance in Ogun state secondary schools (Nigeria): implications for counseling for national development.' European Journal of Social Sciences, 13(2), 229-242.

x. Ayanful, R. (2016, June 20). Private schools call for government assistance. News Ghana. Retrieved 27th July, 2016 from https://www.newsghana.com.gh/private-schools-call-for-government-assistance/

xi. Bawa, E. A. (August 30, 2012). Ghana's educational policy: proposal for the political parties. Joy Online. Retrieved 19th November, 2014, from http://opinion.myjoyonline.com/pages/feature/201208/93074.php

xii. Braimah, A. I., Mbowura, C. K, \& Seidu, A. M. (2014). One state, two school systems: the instability of Ghana's school system since the fourth republic. Journal of Education and Practice, 5(9), 145. Retrieved 8th January, 2016, from http://iiste.org/Journals/index.php/JEP/article/download/11878/12227

xiii. Brown, G. T. L. (2006). Conceptions of curriculum: A framework for understanding New Zealand's curriculum framework and teachers' opinions. Curriculum Matters 2. Retrieved 4th December, 2015, from http://www.nzcer.org.nz/nzcerpress/curriculum-matters/articles/conceptions-curriculum-frameworkunderstanding-new-zealand-s-

xiv. Cassady, J. M. (2011). Teachers' attitudes toward the inclusion of students with autism and emotional behavioral disorder (abstract). Electronic Journal for Inclusive Education, 2 from http://corescholar.libraries.wright.edu/ejie/vol2/iss7/5/

xv. Charnor, G. (2015, May 13). How Ghana can improve educational results for its poor children. Modern Ghana. Retrieved 27th July, 2016

xvi. from https://www.modernghana.com/news/617370/how-ghana-can-improve-educational-results-for-itspoor-child.html

xvii. Creswell, J. W. (2013). Qualitative inquiry and research design: Choosing among five approaches (3rd ed.). Thousand Oaks, CA: Sage Publications, Inc.

xviii. Creswell, J. (2009). Research design: Qualitative, quantitative, and mixed methods approaches. Thousand Oaks, CA: Sage Publications.

xix. Dewey, J. (1938). Experience and education. New York, NY: Simon \& Schuster.

xx. Dike, V. (2005). The state of education in Nigeria and the health of the nation. Africa Economic Analysis. Retrieved 14 th October, 2014, from http://www.africaeconomicanalysis.org/articles/gen/education10204234737htm.html

xxi. Etsey, Y. (2005). Causes of low academic performance of primary school pupils in the Shama sub-metro of Shama Ahanta East Metropolitan Assembly (SAEMA) in Ghana. Proceedings of the Regional Conference on Education in West Africa. Dakar: Senegal.

xxii. Eyiah, J. K. (2013, June 5). Fate of Ghana's education system: National agenda needed! Ghana web. Retrieved 14th October, 2014, from http://www.ghanaweb.com/GhanaHomePage/NewsArchive/artikel.php?ID=275876

xxiii. Farley, R., \& Everwine, E. (2014, June). Playing politics with education: Did the governors of Michigan and Pennsylvania cut education funding or increase it? Factchect.Org. Retrieved 15th October, 2014, from http://www.factcheck.org/2014/06/playing-politics- with-education/

xxiv. Frankfort-Nachmias, C., \& Nachmias, D. (2008). Research methods in the social sciences (7th ed.). New York, NY: Worth Publishers.

xxv. Ghana News Agency. (2015, June 23). Ghana urged to give needed importance to education. Retrieved 25th June, 2015, from http://www.modernghana.com/news/625482/1/ghana- urged-to-give-needed-importanceto-education.html

xxvi. Ghana NGOs coalition on the rights of the child (GNCRC). (2014). Convention on the rights of children (CRC) report. UN committee on the rights of the child: Accra, Ghana: Author.

xxvii. Ghana Statistical Service. (2012). 2010 population and housing census (PHC) final results.

xxviii. Ghana Statistical Service (GSS). Accra, Ghana: Author.

xxix. Gibbs, G. R. (2002). Qualitative data analysis: Explorations with NVivo. Buckingham: Open University Press.

xxx. Hilmer, M. J. (2001). Redistributive fee in-creases, net attendance costs, and the distribution of students at public universities. Economics of Education Review, 20(6), 551-562.

xxxi. Inkoom, A. (2012). Implementation of initiatives in Ghanaian education: The effect on rural Ghanaian junior high schools. Berlin: Lap Lambert Academic Publishing.

xxxii. Kothari, C. R. (2004). Research Methodology: Methods and Techniques (2nd ed.). New Age International (P) Ltd., Publishers. ISBN (13): 978-81- 224-2488-1.

xxxiii. Lamiell, P. (2012, November 2). How should politics influence education policy? Press Room: Policy. Retrieved 19th November, 2014, from http://www.tc.columbia.edu/news.htm?articleID=8381

xxxiv. Little, A. W. (2010, August). Access to basic education in Ghana: Politics, policies and progress. Retrieved 14th October, 2014, from http://www.createrpc.org/pdfdocuments/PTA42.pdf

xxxv. Lucas, B. N. (n.d.). Education is a woman's fastest route out of poverty. Access to capital is her ladder. Women's Trust. Retrieved 1st August, 2016 from http://womenstrust.org/programs/education

xxxvi. Mankoe, J. O. (n.d.). Quality assessment of educational reforms in Ghana. Retrieved 3rd August, 2016 from http://www.wikieducator.org/images/2/24/quality_assessment_of_educational_reforms_in_ghana.pdf

xxxvii. Ministry of Education. (2015, June 16). The state of education: Meet the Press Series. Accra, Ghana: Ministry of Education.

xxxviii. Ministry of Education. (2015). Basic education. Accra, Ghana: Ministry of Education. 
xxxix. Ministry of Education. (2013). Ghana education reform 2007. Accra, Ghana: Ministry of Education.

xl. Mwin, D. O. (2016, June 8). Inclusive education policy in Ghana-addressing the varied learning needs of learners. Modern Ghana. Retrieved 20th July, 2016 from

http://www.graphic.com.gh/features/opinion/inclusive-education-policy-in-ghana- addressing-the-variedlearning-needs-of-learners.htm

xli. Ogbemudia, M. I., \& Aiasa, M. V. (2013). Influence of home environment on the academic performance of primary five pupils' in English language in Orhionmwon local government area of Edo State. Merit Research Journal of Education and Review, 1(5), 120-125.

xlii. Patton, M. Q. (2002). Qualitative research and evaluation methods (3rd ed.). Thousand Oaks, CA: Sage Publications, Inc.

xliii. Paul, K., \& Emmanuel, M. (2014, August). Education and politics. Ghana Web. Retrieved 14th October, 2014, from http://www.ghanaweb.com/GhanaHomePage/features/artikel.php?ID=323052

xliv. Poku, J., Aawaar, G. M., \& Worae, T. A. (2013, June). Educational sector reforms in Ghana: a review. Global Research Journal of Education, 3(2), 20-31. Retrieved 18th January, 2016, from

http://www.globalresearchjournals.org/fullarticles/51f8c1c87e6a1.pdfhttp://www.globalresearchjournals.or g/journal/grje

xlv. Sackey, H. A. (2008). Private Returns to Education in Ghana: Implications for Investments in Schooling and Migration. African Economic Research Consortium Research Paper 174: Nairobi, Kenya. https://www.issuelab.org/resources/21816/21816.pdf

xlvi. Sarantakos, S. (1998). Social Research. (2nd ed.). London: Macmillan Press, Ltd.

xlvii. Senge, P. M. (2012). Creating schools for the future, not the past for all students. Leader to Leader. 65: 4449. https://doi.org/10.1002/ltl.20035

xlviii. Tagoe, M. (2011). Lifelong learning and the attainment of the education-related Millennium Development Goals 2 and 3 in Ghana: Is there a critical nexus? International Journal of Lifelong Education, 30(1), 19- 35. doi: $10.1080 / 02601370.2011 .538191$

xlix. Thomas, P. L. (2012). Politics and education don't mix. Radical Scholarship. Retrieved 20th April, 2015, from http://wrestlingwithwriting.blogspot.com/search/label/politics

l. Tilak, J. B. G. (2015, May 13). National policy on education: Issues in financing of higher education in India. Retrieved July 27, 2015, from https://norrag.wordpress.com/2015/05/13/national-policy-on-educationissues-in-financing-of-higher-education-in-india/

li. Tonhoma, S., Makombe T., \& Ncube, R. (2016). Curriculum provisions for children with special educational needs in mainstream schools in Bulaway (abstract). Zimbabwe Journal of Educational Research, 28(2). Retrieved 22nd July, 2016 from http://www.ajol.info/index.php/zjer/article/view/140165

lii. Tyack, D., \& Cuban, L. (1995). Tinkering toward utopia: A century of public-school reform. Cambridge: Harvard University Press.

liii. UNICEF. (2012, April). All children in school by 2015: Global initiative on out-of-school children. Government of Ghana: UNICEF.

liv. Villines, S. (2014, August 3). What is policy? Retrieved 1st July, 2015, from http://www.sociocracy.info/whatis-a-policy/

lv. Yousefi, F. (2010). The effects of family income on test-anxiety and academic achievement among Iranian high school students. Asian Social Science, 66, 89-93. 